\title{
The Study of Socio-Cultural Changes in the Middle Eastern Community's Thoughts
}

\author{
Suryo Ediyono ${ }^{1}$, Istadiyantha ${ }^{2}$, Eva Farhah ${ }^{3}$, Abdul Malik, Ahmad Jazuli \\ ediyonosuryo@staff.uns.ac.id ${ }^{1}$, istadiyantha@staff.uns.ac.id², evafarhah@staff.uns.ac.id ${ }^{3}$, \\ abdul_malik@staff.uns.ac.id ${ }^{4}$,ahmad.jazuli@gmail.com ${ }^{5}$ \\ Faculty of Cultural Sciences, Sebelas Maret University, Jalan Ir. Sutami 36 A, Kentingan, Surakarta, \\ 57126, Central Java, Indonesia,
}

\begin{abstract}
The study explores the socio-cultural aspects of the the Middle East countries. The word Middle East is used as part of an overall global review. In the area where these three major continents have met, three monotheistic religions developed from spiritual belief. In terms of strategic, political, economic, cultural and religious locations the Middle East has become the center of global events. The Middle East is the home and spiritual center of Judaism, Christianity and Islam, and it has vast reserves of crude oil. The Near East region is not only a geopolitical but a cultural and religious area. In this study the term 'Middle East' refers to the cultural sphere, so it does not have certain limits, especially religious and cultural factors in the life of the region's people, which are more of a background portrait for contemporary studies.
\end{abstract}

Keywords: Middle East; Social Change; Social Culture.

\section{Introduction}

Geographically, the definition of the Middle East is not very clear. But historians agree that the meaning of the Middle East is the area that stretches from the Nile Valley to Muslim countries in Middle Asia (more or less the Amur Darya Valley or the Oxus River), from the southeastern Europe to the Indian Ocean. Muslim countries in Asia that are often referred to as the Near East and specifically the Continent of Asia are also called West Asia. It was the United States who popularized the term Middle East after World War II. For a long time the Middle East has been known as a crossroads of what is called the Old World or Afro-Eurasia. Therefore the area is also known by many nicknames, some of which are: land of the birth of celestial religions, land of the seven seas. As a country that has had a high civilization since the past, in this region invasions often occur, both fellow residents of the region and invasion from outside. The invasions brought new races, religions and languages. As a result, there arose a vast community of mosaics, a living museum based on physical types of belief systems, languages and cultures.

For most lay people, the first things that might appear in his mind's compilation were that the first term "Middle East"must have been an area of conflict, the Arab-Israeli dispute, and the center of terrorist activity. People also understand about this area which is very rich in petroleum. At first glance, discussing the "Middle East" was identified with the Arabian peninsula. Basically, it seemed very superficial that the assumptions were incorrect [1]. The majority of lay people, even among the students themselves, do not understand the meaning of the term "Middle East" itself, specifically regarding the terms that are actually geographical or 
geographical naming, and which countries are included in inside of it? No agreement has been reached on the Middle East resolution so far and even the term itself has not been universally agreed. Journalists, statesmen and scholars issued the territory with the Near East, sometimes with the Middle East. Near East is an older term [2]. This was inspired by the understanding of Europeans who thought their territory was in the western world and who also claimed that other regions far away from their territory were the eastern hemisphere. After conquering Constantinople in $1453 \mathrm{AD}$ by the Ottoman Empire under the leadership of Sultan Muhammad the Conqueror (Mehmed II), Europeans began to find their own way to the "eastern world" and there would be rich far away. They then explore the ocean looking for a direct route to the countries producing these spices. When they finally reached the territory of China, they assumed the farthest end of the eastern world had been agreed. That is why they are named the imperial territory of China and its surroundings as "Far East" (Far East). While the Arabian peninsula and its surroundings, which lie between mainland Europe and China, are referred to as the "Near East". In addition to covering Southwest Asia, the term Near East also covers the regions of Southeast Europe which in the past were under the control of the Ottoman Empire. The Middle East terminology appears to be newer, and then became widely accepted today because it is used as an official term by the British people. In understanding followed by modern custom, it is generally used to understand that the Middle East includes all countries located south of the Soviet Union and to the west of Pakistan, and also Egypt on the African continent. Balkan countries in this case are excluded. In some cases where Greek and Aegean need to be included, the Near East term is more widely used because it is an older term. Various descriptions of the Middle East term as mentioned above, mostly expressed by Alfred Thayer Mahan, a Western scholar who studies the Middle East. However, these various notions are considered inadequate and less specific. Another Middle Eastern observer named Marshall C.G. Hodgson revealed that what is meant by "Middle East" are areas stretching from the Nile in the West to the Oxus River in the East (from Nile to Oxus) [3].

Apart from the various meanings mentioned above, in fact today the Middle East region has experienced a revolutionary change that is very visible in the political life of the domestic, economic, social structure, and international relations. The series of processes that have taken place in hundreds of years in Europe and in Western countries in general is depicted in the Middle East in just a few moments, a model of experience rarely seen in human history. This region is undergoing a general transition from traditionalism to modernism, sometimes consciously and planned, often half-conscious and half-planned, and generally averse to change. Secularism has deeply penetrated the foundations of state life, and it is this poison of faith that has led to the moral decline of the leaders of the Islamic State there [4]. It seems so difficult to create unity among the leaders of the Arab States. This is caused by several factors, namely the feeling of Tribalism that is still strong among Arabs, the difficulty of finding figures that can be used as leaders of Arab nations, because of the large ego of the leaders of Arab countries, differences in flow and creed in Islam itself which often becomes very sensitive problems (especially between Sunni and Shi'a) and the interference of foreign parties, especially Western countries with an interest in maintaining the smooth supply of oil to their respective countries [5]. In connection with the development of world civilization, after the beginning of its emergence in the 7th century AD, Islam has laid a solid foundation for hundreds of years later in building a civilization that is very high in the Middle East region. Because Islam is the main breath in this civilization, it is often referred to as "Islamic Civilization". In the next discussion will be explained about the meaning of "Islamic Civilization" and where the difference lies with the term "Islamic culture" [6]. For Indonesia, the Middle East is an important region in terms of the religious equality of the majority of its 
population, economic growth and cooperation, educational cooperation, tourism potential, and cooperation in various other fields. Indonesia has real interests in the region. This region later also became the attention of the world community, including Indonesia. Mainly due to a series of upheaval that has almost never ceased to have a significant influence especially on the Islamic world, including Indonesia. The study of the area is a real need for the Indonesian people. However, studies on the problem in the country are still very limited, so this research will examine the socio-cultural changes that occur in the Middle Eastern region? What factors make the Middle East region interesting to discuss around the world, especially for Indonesia's development?

\section{Methods}

This study uses a library method with descriptive analysis that is qualitative and reflexive hermeneutics. Qualitative research is research conducted through observation, document review, with research that is descriptive in nature and tends to use analysis with an inductive approach. The process and meaning (subject perspective) is more highlighted in qualitative research. The data used are in the form of literature obtained through reference books and online. This is because qualitative research is in line with the conditions of the Middle Eastern culture itself which is a unique branch of humanities. Actual data about the findings that build a new theoretical framework that will make Arabic literature study programs, especially interest in Middle Eastern studies. Whereas the study of the reflexive hermeneutic method through the steps of its analysis: the description method, that is the middle east study is collected, analyzed and interpreted. The results of the description are then interpreted in full and intact, so as to reveal the complete meaning of the Middle East Study understanding. The comparative method is used to compare the social culture and the culture of middle eastern people in order to show the relationship of views. In addition, this method is at the same time also to identify similarities and differences in social culture with Indonesia. The results of the analysis were given a more recent interpretation to find a more comprehensive understanding of Middle Eastern studies for the Arabic literature study program of Sebelas Maret University of Surakarta.

\section{Discussion}

The current situation in several Middle Eastern countries also has an effect on economic life in other countries such as Indonesia. There are two impacts felt by Indonesia, namely direct and indirect impacts. The economic life of a country is never separated from relations between countries. Relations between countries are manifested in scientific, social, political, diplomatic, economic, cultural and defense and security relations. Every country has never been separated from political life. Like there is sugar, there are ants, so where there is community, there is always power. The political life of a country runs dynamically and always flares up from time to time. This is what makes several countries in the Middle East now experiencing political upheaval. Here are some of the factors arising from the upheaval in Middle Eastern countries: (1) Leaders who are dictators, Middle Eastern countries that embrace a political system "a-democracy" (not to mention "totalitarian", "authoritarian" or "dictator") such as in general, regimes in the Arab world gained power through alternatives, because of inheritance (monarchy) or military coups. Most conflicting countries have leaders who tend to be dictators, so citizens feel they cannot fully participate in the administration of 
the state. This is what makes the group encouraging them to express their aspirations. If through a formal and legal method there is no serious response from the government, then the radical way of conducting a demonstration is a way that according to some citizens will get a definite response from the state. As was done in Egypt, Libya, Iraq and Tunisia. (2) Religious ideology and political ideology, as the center of the development of the religion of the Middle East world has a very complex treasure of religious thought. But to a certain extent, the history of the development of religious politics in the Middle East is colored by the symptoms of conflict from a constructive to a destructive level. The great Islamic schools of Sunni and Shia are religious ideologies that show signs of conflict in the 20th century. The tradition of the Sunni and Shia conflict actually occurred after the death of Prophet Muhammad. The culmination in modern history is the iran-ira conflict, where iran represents the Shiite tradition and Iraq does not fully represent the Sunni tradition, but many Sunni kingdoms provide support to the kingdom of Israel. At the State level, Sunni-Shiite conflicts also occur in several countries such as Iraq, Iran, Saudi Arabia and Lebanon. Some are in the form of marginalization of Shi'ite groups especially in Iraq, Saudi Arabia and Sunni communities are also marginalized, particularly in Iran, or in the form of power rotations in Lebanon, where religious groups copy political alliances with one another. (3) Conflicts between communities in the Middle East conflict, in the context of conflicts between communities, many occur in locations that experience very high conflict escalation. This pattern cannot be separated from the problem of conflict at the state level. This means that if a country has a conflict vulnerability it will experience a spiral effect on society. Emerging cases occurred in Palestine, Iraq and in Israel. In the case of Palestine, conflicts often occur when resistance factions in Palestine get delematic positions due to the results of negotiations carried out by the Palestinian Authority against Israel. In the case of the Oslo Rahisia agreement between Arafat and Rabin, it eventually led to conflict between the pelestina communities themselves. Likewise the gazajerico first case which will provide a confirmation for the involvement of Palestinian citizens to work in Israel with Arafat's confession must fight the other Palestinian resistance wing. This case also appeared again when Israel gave birth to the structure of the prime minister of the Palestinian government structure which placed Mahmud abbas in line with the Arafat camp. (4) Border, there is a tendency for border conflict patterns that develop in the Middle East many caused by two factors: first, natural factors, namely border conflicts caused by boundary conditions that allow the migration process between the State to run intensively. This matter can be understood because the border area between countries is not limited by nature [7].

Second, artificial, namely border conflict caused by changes in the previous border after a new policy. One very dominant variable is the colonial government policy which often creates border lines by crashing into natural border lines such as ethnicity, rivers, mountains. This is what then causes the symptoms of separatism and irredentism, which is a symptom of separating from a country because of ethnic differences to then join with other countries that have ethnic similarities. Cases of border conflict between Iran, Iraq, Kuwait, Jordan, Syria, Libya are mostly due to this problem. Conflicts that occur in countries in the Middle East region have given shocks to the global economy, this we can see directly on the conditions in the capital market with indicators of ups and downs of the composite stock trading index on all exchanges in the world. The last condition that we can say is this revolution, happened in various countries that was started by the overthrow of President Ben Ali from Tunisia and President Mubarak from Egypt. Where both have been in power for so long. The impact of the conflict in the Middle East on the global economy is certainly making very reasonable concerns. As we all know this region is a very strategic region in world trade traffic including 
oil other than vegetable oil and wheat. In the Middle-East region there is also a kind of sacred load that is the existence of holy cities such as Mecca, Medina, Jerusalem, Karbala, and also Qom. Within a certain extent this phenomenon then gave birth to a new trend that is the pilgrimage tourism business to the holy sites. Egypt here plays an important role as a country through which the Suez Canal passes, which connects the red sea and Mediterranean. The ongoing conflict in the Middle East will certainly make world economic conditions especially oil prices difficult to overcome. On one side this condition has caused anxiety and even fear for all those who work and live in the Middle East. Thousands of people have now left the Middle East and returned to their home countries. No exception for the Indonesian people who work in several companies in Egypt and Libya. The impact of the Middle East Crisis on Indonesia, in the short term will not have a direct impact on the value of Indonesia's trade. The rational reason is that direct trade relations between Indonesia and the Middle East are indeed very small. So far, Indonesia's export market is more directed towards the Asian region than the Middle East region [8].

In the theory of modernization, Tipps mentioned the theory of dichotomy. This type of theory is the process of transforming traditional societies into modern societies [9]. Thus, there is a dichotomy between traditional and modern society. According to Herbert Spencer, society is an organism - something that lives -. In other words, people always experience growth, development and change. The emergence of modernization is often associated with social change, an important change in social structure (patterns of behavior and social interaction) [10]. And we should see social change as something inherent in the nature of something, including in the nature of social life. When talking about the physical realm, human history or human intellect, we find that nothing is permanent, but that everything is always in motion, and its condition changes. Reality is not static, as observed by the ancient Greek philosopher Heraclitus, that all beings always flow, constantly changing, constantly being created and disappearing. As also revealed by Ibn Khaldun about the theory of the cycle of civilization, that in social life, there is always a shift in lifestyle, from nomadic to sedentary [11]. Or as Toynbee said that the transfer (mutation) from primitive societies towards civilized societies, or from static conditions to dynamic directions, is a natural thing in the history of human civilization [12]. The change was passed through three processes: first, the nomadic period. That is a form of life experienced by nomads in the desert, the Barbarians in the mountains, or the Tartars in the grasslands. Second, the time of formation of the organization, which is a time to form a force in the form of a bond (organization). Third, the period of civilization. A time filled with luxurious lifestyles, full of art, open thinking, even secular, materialistic. All of that happened quickly because of the current of globalization [13]. With globalization, the modernization brought about by Western nations is absorbed quickly by Asian nations. Benjamin Barber states that McWorld is a cultural invader. He will destroy all forms of local culture and change into a new shopping complex called the Mall [14].

Modern concepts are commonly contrasted with tradition. Society is closely related to change. The dynamics in society occur in several aspects, one of which is the culture in the community. Cultural change is a necessity. The existence of modernization has led to a shift in the values and attitudes of people who were initially irrational to rational, and the development of science and technology [15]. With the development of science and technology, society becomes easier to move and push to think more forward. Modernization has also led to a better standard of living, because industries that produce sophisticated communication and transportation tools are one of the efforts to reduce unemployment and improve people's lives. However, with modernization it also causes a consumptive lifestyle [16]. People are easily attracted to consuming goods with many choices available. In addition, modernization also 
leads to individualistic attitudes, westernized lifestyles, and social inequalities. Indeed changes occur everywhere in social life throughout time. Sometimes it happens suddenly and quickly, that is when the system of a government is destroyed by a revolution and replaced by a new system. Sometimes change also happens slowly, that is when members of the community do it slowly.

\section{Conclusion}

The term Middle East is a geographical and geopolitical naming. Geographically, the definition of the Middle East is not very clear. But in terms of history, the Middle East is an area that stretches from the Nile Valley to the Muslim countries of Central Asia (more or less the Amur Darya Valley or the Oxus River), from the southeastern Europe to the Indian Ocean. In the light of modern customs, it is generally understood that the Middle East includes all countries located south of the Soviet Union and west of Pakistan, as well as Egypt on the African continent. The Middle East terminology appears to be newer, and then became widely accepted today because it is used as an official term by the British people. In understanding followed by modern custom, it is generally used to understand that the Middle East includes all countries located south of the Soviet Union and to the west of Pakistan, and also Egypt on the African continent. Balkan countries in this case are excluded. In some cases where Greek and Aegean need to be included, the term Near East is more widely used because it is an older term. Research on the study of socio-cultural changes in the thinking of middle east people to build a community of cooperation between Indonesia and the Middle East oriented to new discoveries and to solving real and current problems. Building a commitment to the values of peace, justice, Indonesian-ness, Islam, and humanity. Develop studies, research, and publications on the Middle East region and Indonesia-Middle East cooperation in the country. Giving birth to new findings related to socio-cultural change with Middle Eastern studies and Indonesia-Middle East cooperation.

\section{Reference}

[1] Sihbudi, M. Riza, "Timur tengah, dunia islam, dan hegemoni Amerika", Jakarta: pustaka hidayah, 1993.

[2] Atieh A., Ben-Nun G., El Shahed G., Taha R., and Tulliu, S. Peace in the Middle East: P2P and the Israeli-Palestinian Conflict, UNIDIR United Nations Institute for Disarmament Research Geneva, Switzerland, 2002, pp.1-39

[3] Haferkamp, Hans, and Smelser, N.J., Social Change and Modernity. Berkeley: University of California Press, c1992. http://ark.cdlib.org/ark:/13030/ft6000078s/, p.13

[4] Godechot, J. "Revolusi di Dunia Barat 1770-1799". Yogyakarta: Gajah Mada University Press, 1989.

[5] Asasuddin, Umar, Peranan Cendekiawan dalam Perjuangan Kemerdekaan Palestina: Pendekatan Sejarah dalam Palestina: Solidaritas Islam Dan Tata Politikdunia Baru, Jakarta: Pustaka Hidayah, 1992.

[6] Kelahan, B., and Penn, M. Spotlight on The Muslim Middle East Crossroads A Student Reader, New York: The American Forum for Global Education, 1996.

[7] Dahlkvist, M. (2019), "The Politics of Islam, NonViolence, and Peace The Thought of Maulana Wahiduddin Khan in Context", [PhD Dissertation], Umeå University, Sweden 2019 
[8] Faturrohman. Isu dan Realita Konflik Kawasan. Yogyakarta: Gajah Mada University, 2010.

[9] Zhukov, D. S., Lyamin, S. K. Computer modeling of historical processes by means of fractal geometry. Historical Social Research, Vol. 35, (2010): 323-350. https://doi.org/10.1177/2158244016640858

[10] Akujobi, C.T and Jack, Jackson T.C.B (2017): Social Change and Social Problems. In Abasiekong, E.M, Sibiri, E.A, Ekpenyong, N.S (eds.) Major Themes in Sociology: An Introductory Text. pp 491-526. Benin City, Mase Perfect Prints.

[11] Önder, M, \& Ulasan, F. (2018), "Ibn Khaldun's Cyclical Theory On The Rise And Fall Of Sovereign Powers: The Case Of Ottoman Empire", Adam Akademi, 8/2 2018:231-266, DOI: 10.31679/adamakademi.453944

[12] Toynbee, Arnold J.1959. Hellenism: The History of a Civilization. London: Oxford University Press

[13] Yamamoto, Y. "Globalisasi And Change in the International System “ Japan Review, Vol 15, No.2, (2011)

[14] Giddens, A. The Consequences of Modernity. Stanford: Stanford University Press, 1990.

[15] Idang, G.E., African Culture and Values, Phronimon, Vol. 16, No. 2, 2015, pp. $97-$ 111

[16] Allbrow, M. and King, E. Globalization Knowledge and Society (eds). London: Sage Publication, 1990. 